\title{
ХРАМОВАЯ АРХИТЕКТУРА ВОЛЫНИ В СОСТАВЕ РОССИЙСКОЙ ИМПЕРИИ (1795-1914 ГГ.)
}

\author{
Петр Рычков
}

\begin{abstract}
В статье предпринята попытка проследить основные направления развития храмовой архитектуры на территории Волынской губернии в составе Российской империи. Этот период в целом характеризувався постепенным усилением Русской Православной Церкви и вытеснением двух других христианских конфессий: греко-католической (униатской) и римско-католической. На этом фоне в церковной архитектуре прослеживаются стилистические течения, основанные на различных творческих парадигмах: классицизма (первая треть XIX века), романтизма, неоготики, византийского стиля, неорусского историзма, модерна, а также их морфологических взаимовлияний.
\end{abstract}

Ключевые слова: классицизм, романтизм, неоготика, византинизм, неорусский исто-ризм, модерн, храмовая архитектура, Волынская губерния.

Храмостроительство по праву считается одним из самых показательных разновидностей архитектурного искусства на всех етапах его исторического развития. Какой бы конфессией не создавались храмы, они всегда становились объектами первостепенной общественной важности - как в локальном измерении конкретной религиозной общины, так и в смысле глобальных символов нации, государства, этноса. В смысле же сугубо архитектурном храмы всегда играли и играют роль важных доминант в застройке городов и сел, а к их проектированию, как правило, причастны ведущие мастера архитектурного и строительного дела. Не далека от истины мысль, что история храмостроительства - это в значительной степени история развития архитектуры в целом. На протяжении веков при сооружении храмов решались вопросы прогресса строительной техники, нарабатывались определенные композиционные приемы и функциональные схемы, формировались особые стилистические каноны. Наконец, именно в сакральном зодчестве наиболее ярко проявляли себя насущные потребности образно-символической и конфессиональной идентификации святынь.

Следовательно, становится понятным познавательный интерес к храмостроительному наследию не только в глобальном измерении, но и в его локальных проявлениях на определенных территориях, которые часто имели свою особую региональную окраску. Одним из таких показательных исторических регионов можно считать Волынь с ее непростым, разновекторным прошлым. Однако если волынское сакральное зодчество средневековой, ренессансной и барочной эпох постоянно привлекало и привлекает к себе внимание исследователей, то храмы, воздвигнутые во время пребывания Волыни в составе Российской империи, долгое время оставались на обочине 
историко-архитектурной аналитики и лишь в последние два десятилетия пробуждается исследовательский интерес к их изучению' ${ }^{1}$.

Тому есть несколько объяснений. Общим фактором, который обусловливал в прошлом снижение исследовательского интереса к архитектурным явлениям этой эпохи, конечно, можно считать традиционные оценки архитектурного искусства XIX века как такого, которое утратило четкие ориентиры развития, попав в плен эклектичных экспериментов и стилистической неопределенности. Относительно особых региональных факторов, здесь стоит принять во внимание изменение культурной парадигмы в целом, вместе со сменой государственной принадлежности Волыни. В сакральном зодчестве эти изменения вылились в культивирование православной церковью таких стилистических форм, которые массово экспортировались на Волынь из центральной России. Вместе с тем следует признать, что это был период, в итоге которого на архитектурной карте Волыни появились сотни новостроек сакрального назначения, значительная часть которых и сегодня определяет особые отличительные черты волынской архитектурного наследия.

Перед присоединением к России по состоянию на конец XVIII века. на Волыни сложилась ситуация, при которой православная церковь практически утратила свое влияние. Зато доминировали две другие христианские конфессии, ориентированные на римскую курию, - римо-католическая и греко-католическая (униатская). Первая конфессия была представлена в архитектуре в основном величественными каменными костелами, вторая - скромнее, преимущественно деревянными церквями. Относительно количественного измерения позднее барокко в католическом храмостроительстве состоянию на 1790 год характеризувалось интересными статистическими даннями, кторые приводит Ежи Ковальчик ${ }^{2}$. Так, на территории луцкого архидеканата проживало около 805 тыс. населения, из которого лишь 250 тыс. составляли представители латинского вероисповедания. Суммарно в течении XVIII века римско-католическая церковь сумела выстроить на Волыни 28 костелов кляшторных и около 40 приходских, - в подавляющем своем большинстве каменных ${ }^{3}$. Храмы же греко-католические преимущественно были деревянными, хотя в количественном отношении многократно превосходили католические святыни. Когда же после второго и третьего разделов Речи Посполитой почти вся Волынь отошла к Российской империи как отдельная губерния (за исключением присоединенной к Австрии Збаражчины), вся эта обширная территория была подвергнута интенсивной культурно-политической, а вместе с тем и конфессиональной русификации. Все это в XIX ст. привело к уничтожению более чем 50 \% каменных католических костелов ${ }^{4}$.

1 См. в частности: Kolosok B. Die evangelische Kirche von Luck - Geschichte der Entstehung und derzeitige Restaurierung // Wolhynische Hefte. - 1992. - N 7. - S. 63-64; Popek L. Świạtynie Wołynia. - T. 1. - Lublin, 1997. - 370 s.; Ричков П., Михайлишин О. Костьол в Невіркові (Рівненська обл.): доля однієї з волинських святинь початку ХІХ ст. // Історія релігій в Україні. - Львів, 1999. - Кн. 2. - с. 76-79; Ричков П. Церква св. Трійці Дерманського монастиря: до історії архітектурних трансформацій // Волинська ікона: дослідження та реставрація. Наук. збірник. - Луцьк, 2003. - Вип. 10. - С. 168-178; Krasny P. Architektura cerkiewna na ziemiach ruskich Rzeczypospolitej. 1596-1914. - Kraków, 2003. - 429 s.; Годованюк О. М. Монастирі та храми Волинського краю. - К., 2004. - С. 136-167; Ричков П. Волинська спадщина Адріана Прахова // Пам'ятки України: історія та культура. - 2008. - Ч. 1. - С. 46-47; Ричков П., Смолінська О. Дерев’яні церкви Волині XIX - початку XX ст.: місцева традиція та зовнішні впливи // Одне надійне життя (до 100-річчя від дня народження Леоніда Маслова). - Луцьк, 2009. - С. 363-375; Ричков П. Міжконфесійний трансморфізм у сакральній архітектурі Волині // Вісник Нац. Ун-ту «Львівська Політехніка». - 2010. - № 674. - С. 351-364; Ричков П. Стилістична еволюція храмової архітектури Волині XIX - початку XX ст. // Студії і матеріали 3 історії Волині. 2013. - Кременець, 2015. - С. 99-128; та ін.

2 Kowalczyk J. Świạtynie późnobarokowe na kresach. Kościoły i klasztory w diecezjach na Rusi Koronnej. - Warszawa, 2006. - s. 103-104.

3 Ibid. - s. 104-105.

4 Kowalczyk J. Kierunki w późnobarokowej architekturze sakralnej na Wołyniu // Sztuka Kresów Wschodnich. Kraków, 1994. - s. 8. 
Конечно, сам факт вхождения Волыни в состав Российской империи не имел прямого отношения к переформатированию стилистических преференций в архитектуре. B последней трети XVIII ст. и в России, и в Речи Посполитой доминировали принципы классицизма, основополагающие принципы которого базировались на подчинении творческого мышления архитектурному ордеру, то есть, иными словами, всеобъемлющему архитектурному «порядку». Классицистическое мировоззрение было своеобразным воплощением иерархической идеи шляхетско-дворянского абсолютизма в строгие и даже суховатые архитектурные формы ${ }^{5}$. Завоевав ведущие позиции еще в XVIII ст., классицизм уверенно сохранял свою программную роль в течение первой трети следующего столетия. Это в равной степени касалось как гражданского, так и сакрального зодчества, хотя, несомненно, главным полем применения классицистических принципов в количественном измерении, конечно же, было дворцовое и усадебное строительство.

После прихода на Волынь российская администрация была крайне заинтересована в утверждении своего влияния во всех сферах общественной жизни. А поскольку в православной России церковь всегда была мощным инструментом внутренней политики, то, понятное дело, стояла стратегическая задача вернуть благочестию его лидирующую роль. Проще всего это можно было сделать за счет переподчинения Московскому патріархату пружних униатских приходов. Правда, первые десятилетия российского администрирования на Волыни при императорах Павле I и Александре II характеризувались определенной толерантностью по отношению к латинскому и униатскому вероисповеданиям, так и в отношении других религиозных общин 6 . Однако с началом царствования Николая І ситуация начала стремительно меняться в пользу православия на фоне новой стратегической цели в религиозной сфере - приобретения православной церковью господствующего статуса. Отмечается, что главной целью религиозной «ориентализации» было ускорение русификации новых земель, присоединенных к Российской империи ${ }^{7}$.

Процесс достижения этой цели условно можно разделить на три хронологических этапа. Первый - это первая треть XIX века, которая завершилась польским восстанием 1831 года. Второй - это отрезок времени до польського восстания 1863-1864 годов. Наконец, третий охватывает промежуток времени до начала первой мировой войны. Каждый из этих периодов характеризовался не только изменениями архитектурной стилистики, но и постоянно возрастающей интенсивностью, с которой российская власть наращивала на Волыни государственную поддержку православному храмостроительству. Именно эта последовательная смена внутриполитических ориентиров обуславливала стратегические ориентиры в дальнейшей эволюции и в масштабах нового сакрального строительства на Волыни. В частности, одним из последствий восстания 1830-1831 годов. стала быстрая ликвидация ордена василиан и уже к 1839 году уния на Волыни была отменена окончательно ${ }^{8}$. После поражения польского январского восстания 1863 года российская власть подняла новую, еще более мощную волну репрессий против римско-католической Церкви и одновременно усилила поддержку Церкви православной с предоставлением ей значительных денежных ресурсов на новое церковное строительство9. Вследствие административных действий в западных губерниях империи в течение последней трети XIX века было возведено около 1700 (!) нових церковных сооружений, на что из казны было израсходовано около 10 млн. рублей ${ }^{10}$. К началу XX века Волынская єпархія имела

5 Иконников А. В. Тысяча лет русской архитектуры. Развитие традиций. - М., 1990. - с. 321.

6 [Петров Н.]. Волынь. Исторические судьбы Юго-Западного края. - СПб., 1888. - с. 245.

7 Яковенко Н. Нарис історії середньовічної та ранньомодерної України. - 2 вид. -К., 2005. - с. 493.

8 [Петров Н.]. Волынь... - с. 280.

9 Жилюк С. Російська православна церква на Волині (1793-1917). - Житомир, 1996. - с. 116.

10 Там же. 
совокупно 1999 храмов и 207 часовен, а по состоянию на 1913 год здесь насчитывалось уже более 2150 церквей ${ }^{11}$.

Другой, профессионально более интересный аспект эволюции сакральной архитектуры Волыни связан с изменением чисто художественных преференций и стилистических течений. Общая логика, последовательность и характер этих изменений, конечно, вполне зависели от общеевропейских архитектурных течений. Однако по-прежнему ощутимое, если не решающее, влияние на храмостроительную практику оказывали также особенности религиозной политики в границах самой Российской империи.

В исторических трудах, посвященных архитектуре России XIX века, эта эпоха характеризуется, как правило, двумя стилистическими парадигмами, которые с определенными замечаниями можно признать правомерными и для исторической Волыни. Первая - это, конечно, классицизм, который часто и небезосновательно определяется в архитектурной историографии как последний «полноценный» и всеохватывающий стиль в истории мирового зодчества. Действительно, в течение предыдущего века классицизм добился глобального, общемирового статуса, чему в первую очередь способствовала его относительно простая, однако очень выразительная и «крепкая» морфологическая система, основанная на доминировании «классических» архитектурных ордеров, композиционной иерархии, четкой симметрии, убедительного пространственного «порядка» и рациональной логики.

На смену классицизму в 40-х годах XIX века постепенно пришло не менее важное явление, вызванное пробуждением интереса к историческому наследию, которое в настоящее время характеризуется преимущественно нейтральным термином «историзм», а ранее имело также свое определение как «архитектуры выбора», то есть архитектуры эклектической. В рамках творческой парадигмы историзма XIX - начала XX веков, конечно в разной степени, находили свое отражение главные стили прошлого - романский, готический, византийский, ренессансный (палладианский), барочный и даже диковинные ориентальные формы («китайщина»). Конечно, все они в аналитическом контексте должны отфильтровываться от своих исходных, «настояних» прототипов с помощью приставки «нео». К тому же в конце XIX века вновь выразительно заявила о себе классицистическая линия, характеризовавшаяся условным термином «неоклассицизм».

После упадка классицизма в церковной архитектуре среди православных иерархов укоренилось общее убеждение, что наиболее приемлемыми следует считать образные ассоциации с тем архитектурным наследием, которое в прошлом формировалось именно в лоне именно этой же конфессии. Следовательно, согласно такой позиции, роль предпочтительных прототипов должны исполнять исконные стилистические морфемы - византийские, коренные древнерусские, «допетровские» московского и ярославского пошиба, а также ихние различные сочетания эклектического происхождения. В то же время российское храмостроительное наследие XVIII века, прежде всего барочное, в целом игнорировалось как такое, которое было сильно обусловлено «чуждыми» (то есть западноевропейскими) воздействиями, а потому пробуждало нежелательные ассоциации с некими католическими прообразами.

Понятно, что для католического клира в такой «конкурентной» ситуации наиболее адекватной позицией по отношению к прошлому опыту казалось соблюдение прежде всего романо-готической традиции, которая несла в себе мощный символический заряд исторической причастности к древним корням западного христианского мира. Схожие ориентиры имели место и среди представителей протестантских вероисповеданий.

Итак, в рамках посткласицистической храмостроительной практики второй половины XIX в., которая в целом основывалась на принципах историзма, можно выделить две стратегические линии. Первая, связанная с благочестием, ориентировалась на знаковые

11 Там же. - c. 16-17. 
явления своего собственного прошлого. Вторая стратегическая линия, свойственная прежде всего католической и протестантской конфессиям, ориентировалась на образные архетипы романской и готической эпохи, прежде всего в тех ихних проявлениях, которые получили широкое распространение на территории Польши и ее ближайших западных соседей. Следует заметить, что эти два стратегических направления подпали под определенные концептуальные «возмущения» на рубеже XIX и XX веков, что было вызвано некоторой либерализацией религиозной жизни в России, а также новыми стилистическими поисками. В это время дают о себе знать неоклассицизм, модерн, возрождается интерес к местному храмостроительному наследию, в том числе вернакулярному. Последняя тенденция, конечно, не могла существовать в чистом, рафинированном виде, а поэтому, маскируясь, вплеталась в контекст других неостилей.

Особым явлением в сакральной архитектуре Волыни указанного периода стали нередкие случаи архитектурного трансморфизма, генетически тесно связанного именно с сакральной архитектурой. Это отдельная весьма актуальная тема, которая вполне заслуживает содержательного выделения. И хотя автору приходилось касаться ее ранее ${ }^{12}$, следует признать, что данная исследовательская проблематика далека от своего всестороннего освещения.

В первые десятилетия российской власти на Волыни доминирующим вероисповеданием все же оставалась римо-католическая церковь, которая была прямо связана с польским населением в крае, с местной аристократией и за которой на протяжении предыдущего столетия прочно закрепился особый статус господствующей, квазиофициальной конфессии. Конечно, при таких благоприятных условиях католическое храмостроительство получило прежде широкое распространение и было представлено на Волыни многочисленными костелами и монастырями.

Идейные истоки неоготических предпочтений, как и романтизма в целом, коренились, очевидно, в отрицательной реакции на сухой, закостенелый классицизм, который в правление императора Николая II приобрел выразительные символические аллюзии с бюрократией, административным засильем, авторитаризмом.

В последних российских исследованиях главная цель массового строительства новых церквей сформулирована еще более определенно: «...они [церкви - П.Р.] должны были стать наглядным свидетельством высочайшей власти и господствующей религии. Применяя власть и репрессии по отношению к католикам (мятежникам), государство одновременно восстанавливало справедливость по отношению к православному населению, которое оставалось в меньшинстве и как нация, и как конфессия $\rangle^{13}$. Понятно, что такая установка находила свое воплощение и в распростаненных архытектурных трансморфизмах по схеме «бывший костел - новая церковь».

Стоит отметить, что в первой половине XIX века на распространение классицизма среди православных новостроек ощутимое влияние имело распоряжение российской власти, чтобы польские помещики на свой счет ставили новые церкви там, где был красивый костел, но не было хорошей церкви. А в случае отказа предписывалось силой отбирать костельные здания и отдавать их православным. Существует несколько известных примеров такого строительного принуждения (Млынов, Александрия), очевидно, вполне понятого, учитывая потребности православных прихожан.

Классицистических храмов на Волыни сохранилось относительно немного. Одним из первых на Волыни можно считать каменный приходской костел св. Юзефа и св. Эльжбеты в южноволынском городке Колодно. Известный иконографический материал

12 Ричков П. Міжконфесійний трансморфізм... - с. 351-364.

13 Градостроительство России середины XIX - начала XX века. Общая характеристика и теоретические проблемы. - М., 2001. - с. 235. 
демонстрирует на его главном фасаде необычный симбиоз барочного фронтона и классицистического четырехколонного портика ${ }^{14}$. Причины подобной стилистической коннотации кроются, очевидно, в том, что строительство этого костела началось еще в 1782 году на средства Леонарда Свейковського, а закончено было почти через два десятилетия в 1801 году ${ }^{15}$. То есть, похоже на то, что портик стал более дополнением к уже существующему позднебарочному храму.

Одним из первых классицистических костелов на Волыни можно считать также доминиканский костел в Невиркове (рис. 1). Он был спроектированный польским архитектором. Г. Минтером в довольно монументальной манере на принципах позднего классицизма с величественным шестиколонным портиком и пристроенными к нему симметричными крыльями монашеских келий ${ }^{16}$. В силу неизвестных обстоятельств, этот проект однако не получил полномасштабной реализации. В процессе строительства шестиколонный портик был заменен на четырехколонный, а боковые корпуса келий вообще не были построены. Предполагается, что эти изменения внес в проект другой архитектор - Ш. Б. Цуг, который спроектировал в соседних Межиричах Корецких изысканный класицистический дворец для семьи Стецких ${ }^{17}$.

В начале XIX века. был построен костел в Мизоче, основанный еще в 1759 году, однако законченный только в 1830-х годах на средства семьи Дунин-Карвицьких. В советское время храм, к сожалению, получил серьезные повреждения, а впоследствии был приспособлен под православную церковь с соответствующими стилистическими и композиционными трансформациями.

Чтобы уберечь от закрытия католический костел в местечке Млынове, в 1830 году на средства графа Александра Ходкевича началось строительство каменной церкви Александра Невского в стиле классицизма, завершенное в 1840 году. Впоследствии она была переосвячена как Покровская. Достаточно монументальная композиция этого одноглавого безстолпного храма имеет центричное объемно-пространственное решение с крещатым планом, главное входная часть которого акцентирована четырехколонным портиком тосканского ордера (рис. 2). Храм был полуразрушен во время первой мировой войны и восстанавливался в 1920-е годы, что повлекло за собой некоторые потери в архитектурном оформлении.

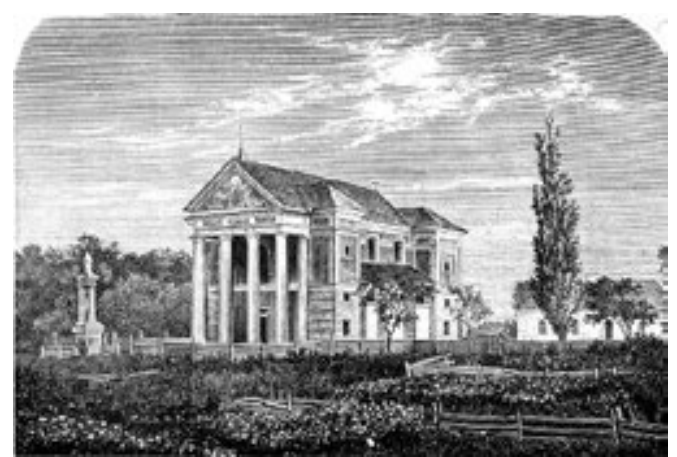

Рис. 1. Доминиканский костел в Невиркове. 1807 г. Гравюра 2-й пол. XIX в.

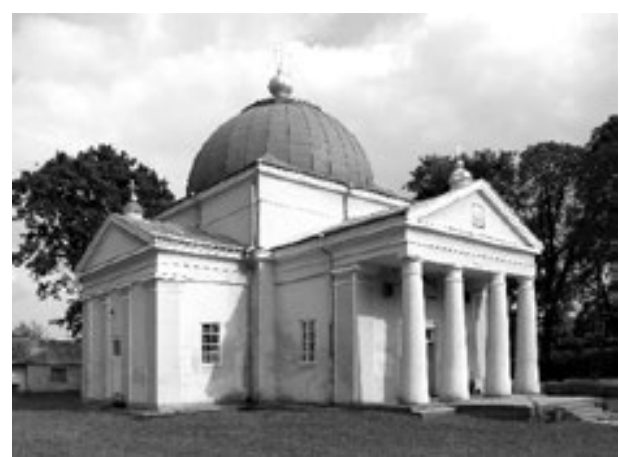

Рис. 2. Покровская церковь в Млынове. 1830-1840 pp. Фото автора.

14 Popek L. Świạtynie... - s. 114-115, fot. 246.

15 Orłowicz M. Ilustrowany przewodnik po Wołyniu. - Łuck, 1929. - s. 366.

16 Ричков П., Михайлишин О. Костьол в Невіркові... - с. 76-79.

17 Там само. - с. 79 
Своеобразным примером классицистической церкви может служить каменный Николаевский храм в Корце (рис. 3), построенный в 1836 году на средства князя Ю. Чарторийского ради избежания закрытия местного католического костела ${ }^{18}$. В основу его планировочной композиции была положена принципиально иная, трехчастная схема (притвор - неф - алтарь), которая издавна являлась наиболее распространенной в народном церковном зодчестве Волыни. Вместе с тем выглядит достаточно необычным решение неизвестного архитектора пристроить с юга и севера к главному объему классицистические восьмиколонные портики со спаренными колоннами тосканского ордера. Это был необычный оригинальный прием, который больше нигде не встречается в данном регионе. Тогда как главный вход с запада был оформлен лишь четырехколонным портиком. Такую необычную композиционную схему в использовании ордера, наверное, можно объяснить окружающей средой, когда южная сторона церкви ориентировалась на пространственный центр городка с регулярной восьмибичною площадью (сегодня полностью утраченной), а южная должна была радовать глаз с территории замка. За своими физическими измерениями эту довольно величественное сооружение можно считать одним из самых монументальных образцов среди классицистических церквей на Волыни.

Среди более скромных храмов, построенных в классицистическом стиле в первой половине XIX в., следует также упомянуть каменную Преображенскую церковь в Александрии (рис. 3), построенную в 1842 году и интересную тем, что средняя часть ее трехчастного плана имеет овальную форму. Подобная планировочная схема была применена также в Старом Острополе вблизи Староконстантинова.

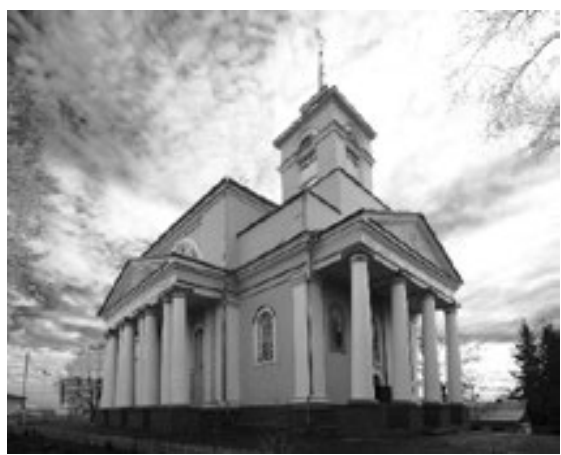

Рис. 3. Николаевская церковь в Корце. 1834 г. Фото автора.

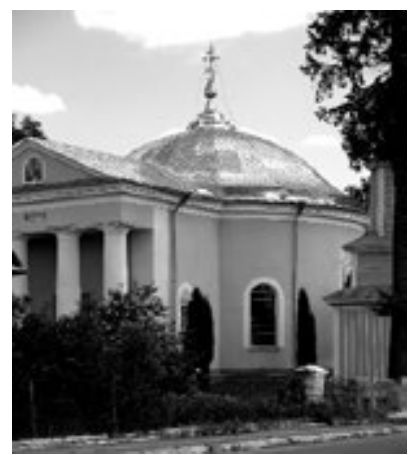

Рис. 4. Преображенская церковь в Александрии. 1842 г. Фото автора.

В первой половине XIX века было построено еще несколько каменных классицистических храмов. Среди православных церквей следует упомянуть: Иоанно-Зачатьевскую в селе Тышковичи Волынской обл. (1838 г.) ${ }^{19}$; Преображенскую в селе Старый Острополь Хмельницкой обл. $(1840 \text { г. })^{20}$, лаконичная объемная композиция которой, правда, недавно была ощутимо искажена надстройкой небольшой деревянной колокольни над притвором; св. Троицы в поселке Главное Волынской обл. $(1841 \text { г. })^{21} ;$ св. Троицы в поселке Головнэ Волынской обл. (1841 г.); Рождества Богородицы в Кодне (1841 г. $)^{22}$; св. Петра

18 Orłowicz M. Ilustrowany przewodnik po Wotyniu... - s. 248.

19 Годованюк О. М. Монастирі та храми... - с. 139.

20 Памятники градостроительства и архитектуры Украинской ССР. - К., 1986. - Т. 4. - с. 231.

21 Там же. - К., 1985. - Т. 2. - c. 95.

22 Там же. - c. 150 
и Павла в селе Свитязь (1846 г. $)^{23}$. Среди поздних классицистических сооружений стоит упомянуть также две постройки в Почаевской лавре: архиерейский дом (1820-1825 гг.) и относительно небольшой, но очень показательный, стилистически выверенный надвратный корпус, построенный по проекту малоизвестного архитектора Михайловского в 1835 году ${ }^{24}$.

Отдельные классицистические видоизменения (дополнения, достройки, перестройки) получили некоторые старые каменные церкви. В частности, это касается Преображенской церкви в Дубно, Троицкой церкви Дерманского монастыря (перестроена в 1840-х годах) и некоторых других.

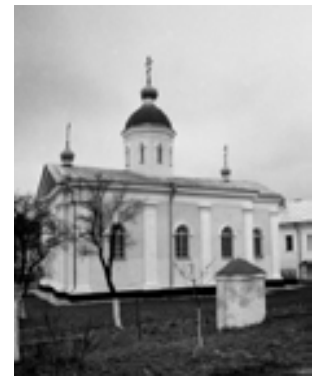

Рис. 5. Троицкая церковь Дерманского монастыря после перестройки 1840 года. Фото автора.

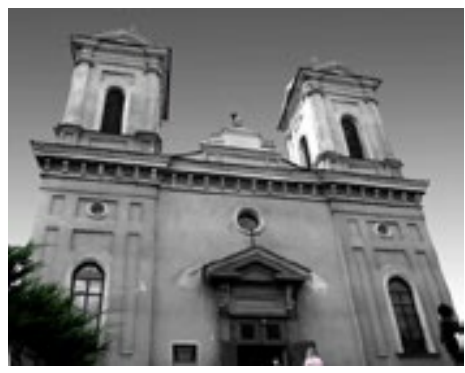

Рис. 6. Приходской костел св. Станислава в Кременце. 1853-1857 гг. Фото автора.

Пример восстановления древней Троицкой церкви в Дермани после того, как она сильно пострадала от пожара в 1828 году ${ }^{25}$, является особенно показательным. В архивных фондах хранится первый нереализованный проект церкви (1830 г.) с использованием выразительных неоготических форм авторства волынского губернского архитектора Антона Шурихта ${ }^{26}$. Появление проекта православной церкви в неоготическом стиле, да еще и выполненного государственным служащим, выглядит достаточно неожиданным явлением для Волыни, поскольку позиции классицизма в это время все еще казались незыблемыми. В качестве объяснения можно отметить немецкое происхождение архитектора (его отец Кристиан Шурихт был известным архитектором в Саксонии и Чехии). Возможно, архитектор ориентировался на творческие новации архитектора А. Менелаca, который по инициативе императора Николая I построил в Петергофе и Царском Селе целый ряд зданий, которые фактически положили начало неоготическому направлению в архитектуре России. Фактически это была новая альтернатива консервативному классицизму ${ }^{27}$. Однако, когда проект А. Шуріхта попал на согласование к православному епископу Волынскому и Житомирскому Амвросию, он не был утвержден. В итоге была согласована классицистическая версия восстановления церкви, разработанная вышеупомянутым архитектором Михайловским в 1840 году и реализованная в последующие годы (рис. 5).

23 Там же. - с. 97.

24 Ричков П. А., Луц В. Д. Почаївська Свято-Успенська лавра. - К., 2000. - с. 70, 77.

25 Ричков П. Церква св. Трійці Дерманського монастиря... - с. 168-178.

26 Российский государственный исторический архив, ф. 1488, оп. 1, д. 637, л. 1-2 (План и фасад на переделку каменной церкви, состоящей при Острожско-Дерманском первоклассном монастыре (копия). Составил ... 1830 года волынский губернский архитектор Шурихт).

27 Кириченко Е. И. Архитектурные теории ХІХ века в России. - М., 1986. - с. 39-40. 
Среди католических храмов кроме вышеупомянутого доминиканского костела в Невиркове в первой половине XIX века. были также сооружены нижеследующие классицистические костелы: св. Станислава в Старом Вишневце $(1811 \text { г. })^{28}$, приходской в Скурчах $(1803 \text { г. })^{29}$ Архангела Михаила в Степани (1803-1806 гг. $)^{30}$, Вознесения Господня в Горохове $(1808 \text { г. })^{31}$, приходской св. Каэтана в Березном (1813-1817 гг. $)^{32}$, св. Варвары в Бердичеве $(1826 \text { г. })^{33}$. К сожалению, только последний дошел до нашего времени в более-менее аутентичном виде, тогда как вишневецкий теперь представляет собой печальную руину, а остальные вышеуказанных костелы болем не существуют.

Отдельного упоминания заслуживает хорошо сохранившийся костел св. Станислава в Кременце ${ }^{34}$ (рис. 6), который стал последним католическим храмом на Волыни, исполненным в позднем классицистическом стиле в течении 1853-1857 гг. Это единственный классицистический храм с довольно массивными и строгими формами, который дошел до нашего времени практически без изменений. Главной причиной тому, очевидно, стало то обстоятельство, что храм практически не прекращал выполнения своей первоначальной сакральной функции. Иногда отмечается его композиционное и стилистическое сходство с петербургским костелом св. Екатерины ${ }^{35}$, хотя подобное сравнение довольно условное и неочевидное.

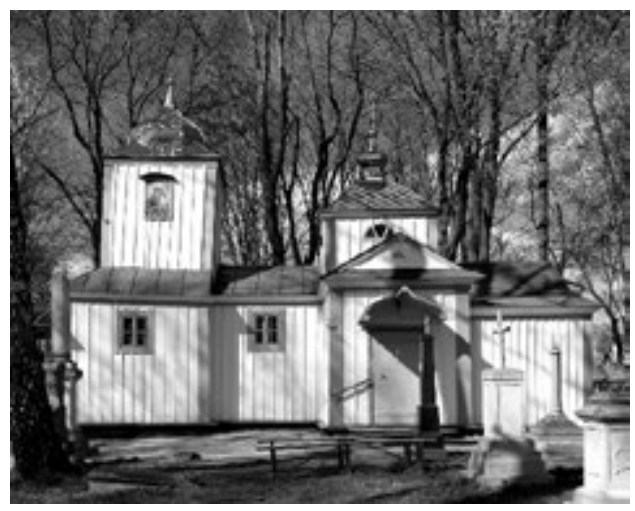

Рис. 7. Стефановська церковь в Ровно. 1848 г. Фото автора.

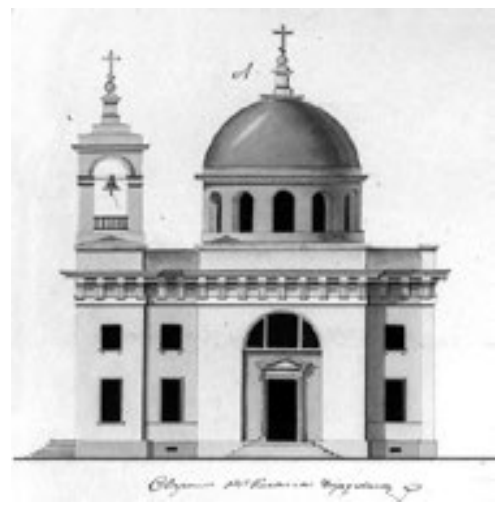

Рис. 8. Николаевская церковь в с. Дубляны Демидовского р-на, проект. 1835 г. Из фондов РГИА.

Доминирование классицистического тренда в каменной сакральной архитектуре Волыни первой половины XIX в. почти не отразилось на деревянном церковном зодчестве. Как одно из нетипичных исключений можно рассматривать Стефановскую церковь в Ровно (рис. 7), построенную в 1850 г. на городском кладбище на средства Екатерины Красовской на могиле супруга генерала Стефана Красовского. Это небольшой одноглавый деревянный, крестообразный в плане храм с рравновысокими прямоугольными срубами. Над центральным срубом находится второй ярус в виде четверика

\footnotetext{
28 Popek L. Świạtynie... - s. 123.

29 Ibid. - s. 154.

30 Ibid. - s. 184.

31 Ibid. - s. 63.

32 Ibid. - s. 88.

33 Памятники градостроительства... - К., 1985. - Т. 2. - с. 147.

34 Popek L. Światynie... - s. 115.

35 Ibid.
} 
с полуциркульными окнами, завершающийся четырехскатной крышей с небольшим куполом. С западной стороны почти равностороннего пространственного креста церкви пристроена двухъярусная колокольня, в которой устроен главный вход в храм. По некоторым признакам (треугольные боковые фронтоны, форма окон центрального подбанника) все-таки угадывается влияние позднего классицизма.

Показательной иллюстрацией изменения стилистического направления в храмостроении Волыни в течении 1830-1840-х годов можно считать историю со строительством Николаевской церкви в с. Дубляны Демидовского района Ровенской области. В 1835 году она была запроектирована в характерних классицистических формах (рис. 8). Однако впоследствии проект претерпел коренные изменения, в результате которых строительство было завершено в 1848 году уже в неорусском стиле с пятью крупными луковичными главами (рис. 9). Очевидно, что эти изменения не обошлись без образных корреляций с новой Десятинной церковью в Киеве, которая была построена на месте древнерусского храма в течение 1828-1842 годы по проекту петербургского архитектора. Стасова.

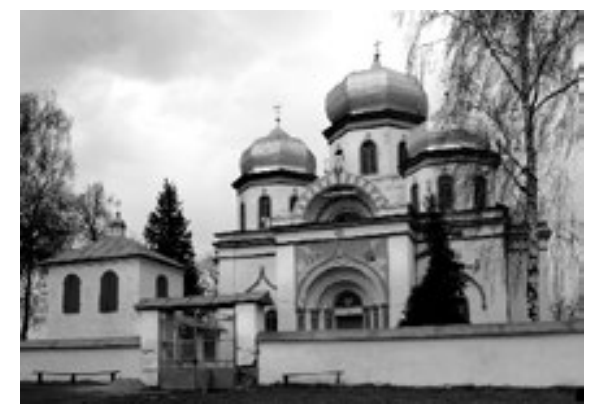

Рис. 9. Николаевская церковь в селе Дубляны, реализованный вариант храма. 1849 г. Фото автора.

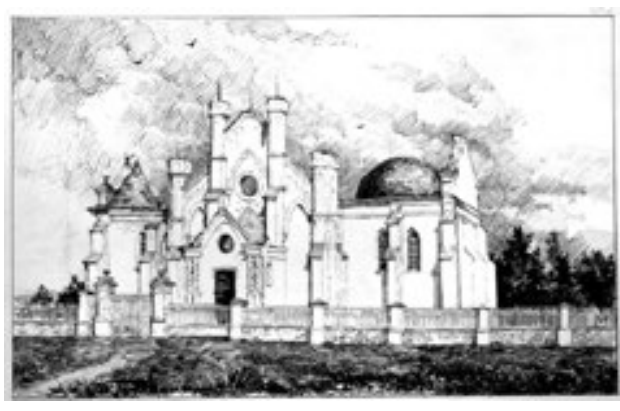

Рис. 10. Руины неоготического приходского костела в Остроге после пожара. 1888 г. Из собрания Национального музея в Варшаве.

Не менее показательным примером стилистических преобразований в последовательности «упрощенное барокко - неоготика - неоклассицизм» является приходской Успенский костел в Остроге. Первый католический храм появился здесь еще в XVI веке. на территории пригородка, в непосредственной близости к замку Острожских. Известные его изображения свидетельствуют о его достаточно лаконичной объемно-пространственной композиции. В 1880 году этот храм был существенно перестроен, в результате чего он получил неоготический вид со стремительными шпилями, которые выразительно прочитывались в городском силуэте ${ }^{36}$. Однако в таком виде он просуществовал недолго и в 1888 году был уничтожен пожаром (рис. 10). А когда было принято решение о его восстановлении, то в качестве архитектурного стиля был выбран неоклассицизм (рис. 11). Такой выбор объяснялся двумя требованиями местной российской администрации: чтобы, во-первых, реконструированное здание костела не превосходило по высоте соседнюю Богоявленскую церковь, которая только что была отстроена из руин, а во-вторых, необарочный и неоготический стили объявлялись non grata из соображений семантической близости к католической традиции. Итак, появился более «нейтральный» неокласицистический вариант.

Отход храмостроительной практики от классицистической парадигмы в середине XIX века сопровождался проникновением на Волынь других исторических стилей. 
Условно можно выделить два основных альтернативных, а в чем-то даже конфликтных стилистических направления: неорусское с различными вариациями и неоготическое, которое временами ассимилировало в себе элементы стиля романского и его осовремененных европейских ризновидностей. Первое направление в силу своїх образних и семантических особенностей было органично встроено в систему архитектурных преференций православной церкви и поэтому, конечно же, стало доминантным в ортодоксальном храмостроения второй половины XIX в. Второе направление ассоциировалось прежде всего с неправославными христианскими конфессиями (католической и различными протестантскими).

Тем не менее, хронологически неоготика значительно опережает неорусский тренд. Одним из ее побуждающих факторов можно считать миграцию на эти земли немецкого этноса, который в большинстве своем был связан с протестантским вероисповеданием. Можно предположить, что и первый известный на Волыни протестантский храм, евангелическая кирха, построенная в 1783 году в Корце немецкими мастерами фарфоровой мануфактуры ${ }^{37}$, уже отличалась неоготический формами.

Одним из самых ранних примеров среди неоготических костелов посткласицистического периода стал храм в Катербурге (ныне Катериновка), построенный в 1854-1877 годах ${ }^{38}$ местной католической общиной (не сохранился). Это была трехнефная базилика, на главном фасаде которой отчетливо прочитывались вертикальные стрельчатые членения, а главный вход был решен в виде перспективного портала.

Оригинальным архитектурным решением отличался также неоготический костел Непорочного зачатия в Шумске (рис. 12). Построенный на средства Л. Менжинской, освященный в 1861 году ${ }^{39}$, этот своеобразный храм принадлежал к уникальным образцам провинциального храмостроения Волыни. Его образ характеризовался сочетанием морфологических признаков позднего классицизма и явно доминирующей неоготики ${ }^{40}$. Очень оригинально виглядели две симметричные башни-колокольни с необычными шатрами так называемого «зонтичного» типа, дополненные по углам острыми пинаклями. В совокупности все это создавало очень активный, острый силуэт всего здания. К сожалению, шумский костел был взорван советской властью в 1985 году. Только в начале XXI века усилиями местной католической общины костел был отстроен Однако вернуть его первоначальный образ в погной мере уже было невозможно.

37 Костюк М. Німецькі колонії на Волині (XIX - початок XX ст.) - Тернопіль, 2003. - с. 28.

38 Popek L. Świạtynie ... - s. 113.

39 Ibid. - s. 159.

40 Ibid. - s. 121. 


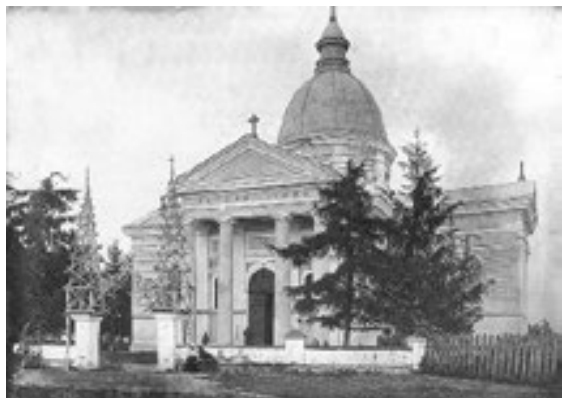

Рис. 11. Приходской костел Успения Богородицы в Остроге. 1897 г. Фото О. Прусевича.

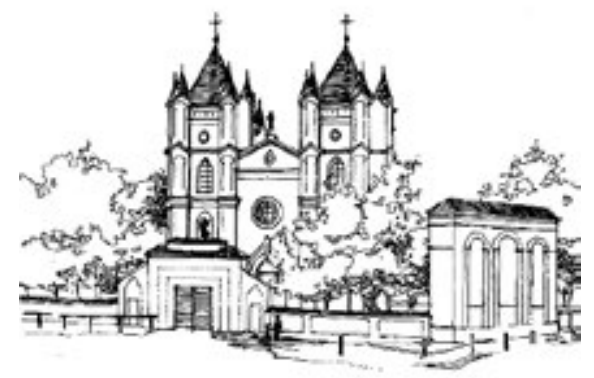

Рис. 12. Неоготический костел Непорочного зачатия в Шумске. 1852 р. Прорись автора по фото 1930-х гг.

На фундаментах старой оборонной башни Новомалинського замка вблизи Острога в первой половине XIX в. была сооружена также относительно небольшая, однако чрезвычайно импозантная неоготическая часовня, запроектированная, как предполагается, известным скульптором Оскаром Сосновским (рис. 13). Сегодня от нее остались только руинированные фрагменты кирпичных стен, однако и в таком полуразрушенном виде она производит довольно живописное впечатление.

Католический костел в Ровно издавна существовал на очень выгодном участке вблизи юго-западного угла старой рыночной площади. Он нескольо раз отстраивался и перестраивался. Существующая нене архитектурная версия храма св. Антония построена в 1899 году при финансовой поддержке Романа Сангушка с участием в проектных работах архитектора К. Войцеховского (рис. 14). Распространенный тогда так называемый «кирпичный стиль» наложил свой отпечаток на архитектурную деталировку храма. К сожалению, после войны костел утратил обе свои башни с острыми шпилями, а последняя его реконструкция в начале 1980-х годов с приспособлением здания для нужд местной филармонии лишила его первозданной образности и, что не менее важно, акцентной роли в панораме историчческой части города.

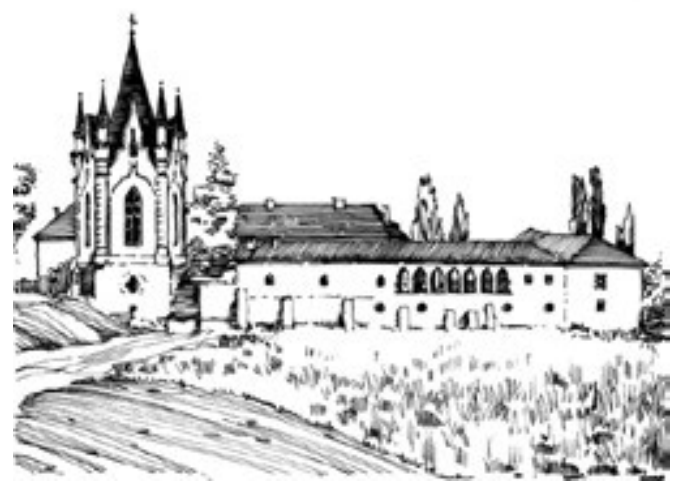

Рис. 13. Неоготическая часовня Новомалинского замка. Первая половина. XIX в. Прорись автора по фото 1930-х гг.

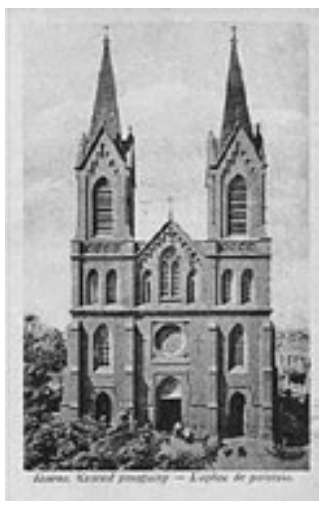

Рис. 14. Приходской костел св. Антония в Ровно. Арх. К. Войцеховский. 1899 г. Открытка 1930-х гг.

Неоготические стилистические черты были присущи и храмам немецких колонистов, которые в последней трети X1X в. выделяются на Волыни в заметное социально-экономическое сообщество, объединившееся преимущественно вокруг евангельсько-лютеранской церкви. К концу ХІХ века в Волынской губернии уже действовало шесть лютеранских приходов, в которых насчитывалось 25 кирх и 197 молитвенных 
домов. При этом общее число лютеран составляло 164425 человек ${ }^{41}$. Представители этой конфессии, демонстрируя хорошие показатели в хозяйствовании и занимая заметное место в общественной жизни края, уделяли большое внимание строительству новых кирх и учебных заведений. Проживая в компактных городских анклавах или, преимущественно, в автономных сельских поселеннях, представители немецкого протестантизма возвели для своих духовних потребностей многочисленные храмы-кирхи ${ }^{42}$, большей частью деревянные. Однако, еще перед первой мировой войной были построены несколько заметных каменных лютеранских кирх, в частности в Луцке и Житомире.

Интересные обстоятельства предшествовали строительству луцкой кирхи. 21 января 1902 года городская власть подарила местной общине «на вечные времена, пока она (община - П.Р.) существовать будет» довольно обширный земельный участок в старом городе для строительства свого храма. Как следовало из документа, дарение предусматривало встречное обязательство - замостить брусчаткой всю прилегающую улицу. И только когда это условие было выполнено, 26 июня 1906 состоялось торжественное заложение фундамента для будущей кирхи ${ }^{43}$. Отреставрированный в последние годы, этот храм является знаковым не только в силу своих выразительных неоготическпих черт, но и как удачный пример интеграции сакрального объекта в образно-символическую структуру города (рис. 15).

Однако стержневое направление сакрального зодчества на Волыни во второй половине XIX в. все же не было связано с неоготическим стилем. В этот период по всей России наблюдается чрезвычайно активная дискуссия относительно необходимости внедрения «национального стиля» в архитектуре и относительно истолкования самого этого понятия. Эта дискуссия, как иногда утверждается, по своей остроте и актуальности не имела аналогии в странах тогдашней Европы ${ }^{44}$. В исследованиях российских историков касательно общественно-идеологических факторов утверждалось буквально следующее: «Эстетическая теория во все времена была связана с действительностью. Но в России второй половины ХІХ в., особенно в 1860-1870-е годы, искусство, художественная критика, теоретическая мысль пронизаны пафосом политической борьбы и всецело подчинены ее интересам... Острота дискуссий, многообразие теорий, давших толчок строительству гражданських зданий в русском «стиле», - все это заставляет считать 1870-е гг. прошлого века вторым после 1830-х - 1840-х гг. отрезком времени, когда наибольшую актуальность пприобрели проблемы национальной архитектуры» ${ }^{45}$.

Такая оценка действительно вполне правомерна по отношению к общероссийской ситуации, точнее по отношению к коренным российским территориям. Однако если в коренной России «архитектурное русофильство» имело совершенно понятные антикосмополитичные, антизападные, «народнические» корни, то для мультикультурной Волыни с ее многовекторным историческим прошлым «навязывание» русского стиля здешней архитектурной практике, на наш взгляд, выглядит как мотивированное сугубо внутриполитическими, идеологическими соображениями. Поєтому оно было далеко от профессионального понимания архитектурных традиций в так называемом «Юго-Западном крае» империи. Особенно отчетливо эта внепрофессиональнгая обусловленность просматривалась в сакральной архитектуре. Во второй половине XIX в. практика

41 Надольська В. В. Лютеранство на Волині в другій половині XIX століття // Матеріали Всеукраїнської наук. конф. до 130-річчя Житомирської... бібліотеки. - Житомир, 1996. - с. 116.

42 Ричков П., Дем'янов В. Протестантські храми на Волині: від найдавніших часів до сьогодення // Записки НТШ. - Львів, 2005. - Т. 249: Праці Комісії архітектури та містобудування. - с. 162-176.

43 Kolosok B. Die evangelische Kirche... - s. 63-64.

44 Кириченко Е. И. Архитектурные теории... - с. 208.

45 Кириченко Е. И. Архитектурные теории... - с. 209. 
храмостроения почти без исключений были представлена новостройками и реконструкциями, которые проводились русской православною церковью при активной поддержке как со стороны местной, так и центральной власти. Мотивация была очевидной - царская администрация и Синод считали православные институты действенным средством преодоления польского, римско-католического элемента и одновременно постепенной ликвидации тех архитектурних традиций, которые формировались в предыдущем веке в лоне как католической, так и греко-католической конфессий.

В 1867-1874 годы в губернском Житомире был построен монументальный, как по провинциональным меркам, кафедральный Преображенский собор в неорусском стиле (рис. 16). Его появление было наполнено двойным символизмом - как крупнейшая, вновь построенная православная святыня Волынской губернии и одновременно как показательный образец официальной архитектурной стилистики, скомбинированной на почве симбиоза российско-московских и византийских традиций. Храм не отличается особой изысканностью форм. Однако, по нашему убеждению, он задекларировал определенные композиционные установки для других церковних новостроек. Прежде всего, - это высокая колокольня с шатровым шпилем, пристроенная к западному притвору церкви, и характерное «пятиглавие» над самим храмом. В дальнейшем аналогичные по композиции и стилю новые церкви становятся не только «визитной карточкой» и популярным архетипом православного храмостроения на Волыни, но и, как не без оснований иногда утверждается, своеобразным инструментом «усмирения» подчиненных народов ${ }^{46}$.

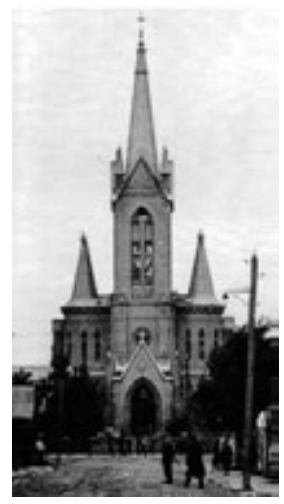

Рис. 15. Евангельско-лютеранская кирха в Луцьке. 1907 р. Фото 1930-х гг.

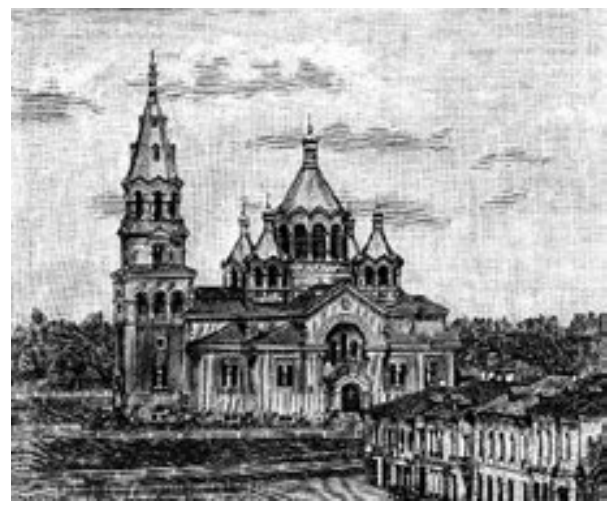

Рис. 16. Преображенский кафедральный собор в Житомире. 1864 г. Гравюра кон. XIX в.

Затем этот композиционный канон десятки, возможно даже сотни раз, находил свое воплощение в небольших местечкових и сельских церквях. В качестве показательного примера одной из таких «реплик» можно привести сходную по композиции и стилю каменную церковь Александра Невского в Радивилове (рис. 17). К тому же этот храм стал своеобразной архитектурной «визиткой» на границе Российской империи с Австро-Венгрией. Любопытно отметить, что эта приграничная полоса представляла для обеих монархий особый интерес с точки зрения демонстрации и репрезентации своей культурно-религиозной идентичности ${ }^{47}$. По ту сторону границы, в приграничном

46 Boberski W. William C. Brumfield, A History of Russian Architecture. - Cambridge University Press, 1993, ss. 644, il.685, il. barw.80 // Biuletyn Historii Sztuki. - 2000. - Nr 1-2. - s. 311.

47 См.: Adelsgruber P., Cohen L., Kuzmany B. Getrennt und doch verbunden. Gegenstädte zwischen Österreich und Russland. 1772-1918. - Wien u.a., 2011. - s.185-190. 
местечке Броды также присутствовала своя особая архитектурная образность, но уже иной греко-католической конфессии.

Среди каменных церквей неороссийского стиля особое место принадлежит Ильинской церкви в г. Дубно, построенной в 1905 году на обочине тракта, ведущего от приграничного Радивилова вглубь империи (рис. 18). Объемные массы этого храма довольно сдержанные. В его основе почти кубический объем собственно церкви с пятью «слепыми» главками, к которому с юга пристроена полукруглая апсида, а с севера - стройная колокольня ${ }^{48}$. Нехарактерная ориентация олтаря на юг унаследовала подобное расположентие от деревянного храма-предшественника, который появился здесь еще в первой трети XVI века, видимо, благадаря своему фундатору - князю Илье Острожскому. Лаконичный образ храма усиливается довольно удачной деталировкой, хотя общая символика полностью остается в русле неороссийского стиля.

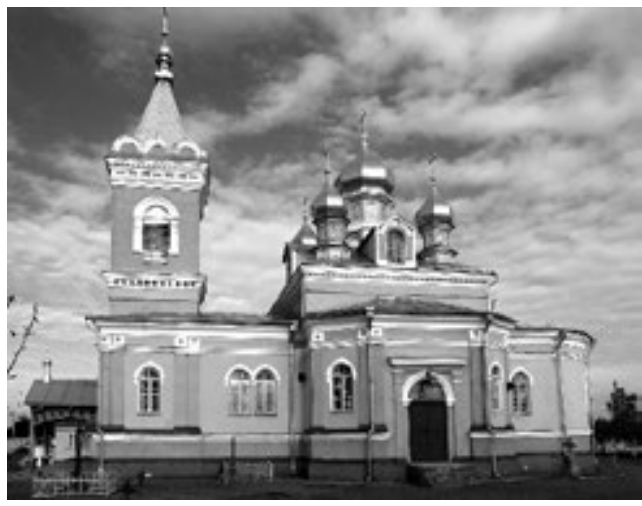

Рис. 17. Церковь Александра Невского в Радивилове. 1874 р. Фото автора.

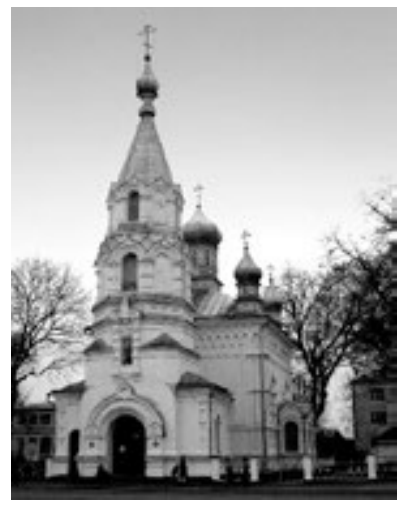

Рис. 18. Иллинская церковь в Дубно. 1905 г. Фото автора.

Примером полномасштабной стилистической трансформации целого монастырского комплекса является бывший францисканский монастырь в Корце. В 1863 году он был переданы в православное ведомство и в течение нескольких следующих десятилетий здесь сформировался обширный ансамбль православного женского Троицкого монастыря с почти полной заменой прежней барочной стилистики костела на стилистику неорусскую. А построенная в 1905 году надвратная колокольня (рис. 19) взяла на себя не только функцию вертикальной доминанты, но и наглядно засвидетельствовала генетическую принадлежность к неорусскому стилю. Однако на главном фасаде монастырской церкви все еще отчетливо проступают фрагменты барочного портала - важной части бывшего францисканского костела.

Тема архитектурного неовизантинизма, появившаяся во второй половине XIX века как способ углубления символических корней русского православия, также оставила свои явственные следы в храмовом зодчестве Волыни. К примеру, она оказалась ведущей в творческом наследии известного художника и исследователя, профессора А. Прахова. Примером ее реального воплощения может служить небольшая церковь-усыпальница в Новой Чартории (1897-1907 гг.), запроектированная на заказ княжны Натальи Оржевской на могиле ее мужа, виленского генерал-губернатора П. Оржевского 99 (рис. 20). Храм довольно скромный по размерам, однако характеризуется весьма искусным

48 Храм имеет необычную ориентацию алтаря на юк, что быдло обусловлено потребностью приспособления церкси к пространству главной улицы - П. Р.

49 Ричков П. Волинська спадщина Адріана Прахова... - с. 46-47. 
обращением, как с общим пропорциональным строем его объемной композиции, так и с архитектурными деталями.

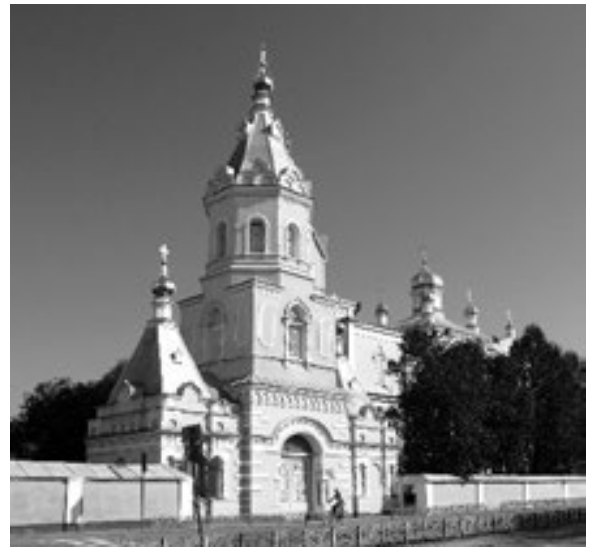

Рис. 19. Надвратная колокольня Троицкого монастыря в Корце. 1905 г. Фото автора.

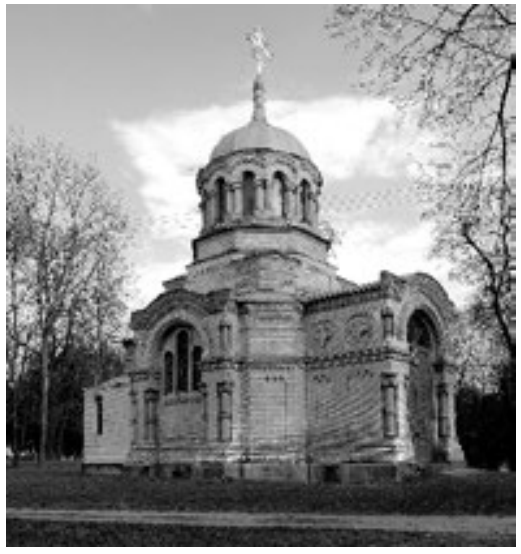

Рис. 20. Церковь-усыпальница в с. Новая Чортория Житомирской обл. 1897-1907 гг. Арх. А. Прахов. Фото автора.

А. Прахову принадлежит также интересный, однако нереализованный проект восстановления Успенского собора во Владимире-Волынском, который засвидетельствовал специфическое авторское видение возможного применения неовизантийського стиля по отношению к знаменитой древнерусской достопримечательности ${ }^{50}$ (рис. 21). Впрочем, по идейным соображениям это необычное проектное предложение было отклонено в среде церковнослужителей, прежде всего через попытки автора сохранить конструктивную структуру предыдущего храма, в частности западный экзонартекс, достроенный греко-католиками в середине XVIII века, а посему, как отмечалось, неприемлемого из идейно-образных соображений. В дальнейшем разработка проекта реставрации Успенского собора и его реализация с полной ликвидацией барочных наслоений была поручена петербургскому архитектору Г. Котову, который пошел по пути гипотетического воссоздания первоначальных архитектурных форм этой действительно знаковой святыни древнерусского пери ода. При этом, несмотря на довольно спорный вопрос относительно первоначального завершения храма (одноглавое, трехглавое, пятиглавое), этот реставраторський проект был признан достаточно убедительным с профессиональной точки зрения (рис. 22). В значительной степени одобрительная оценка была, очевидно, обусловлена разносторонним исследовательским и организационным усилиям А.Прахова в предыдущие годы, в частности при возведении Владимирского собора в Киеве. 


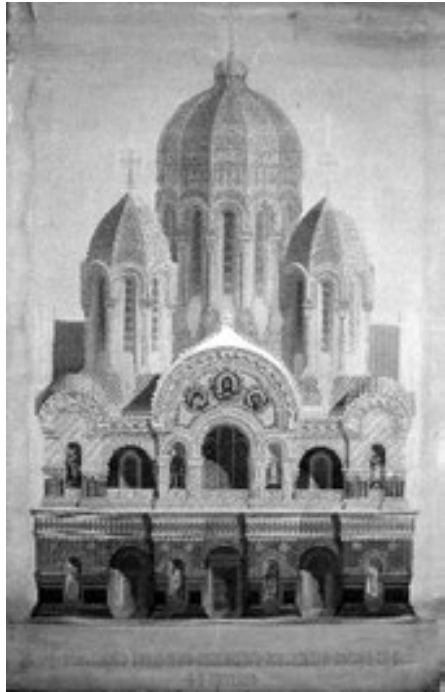

Рис. 21. Проект восстановления Успенского собора во Владимире-Волынском. Арх. А. Прахов. Из фондов Волынского краеведческого музея. Фото автора.

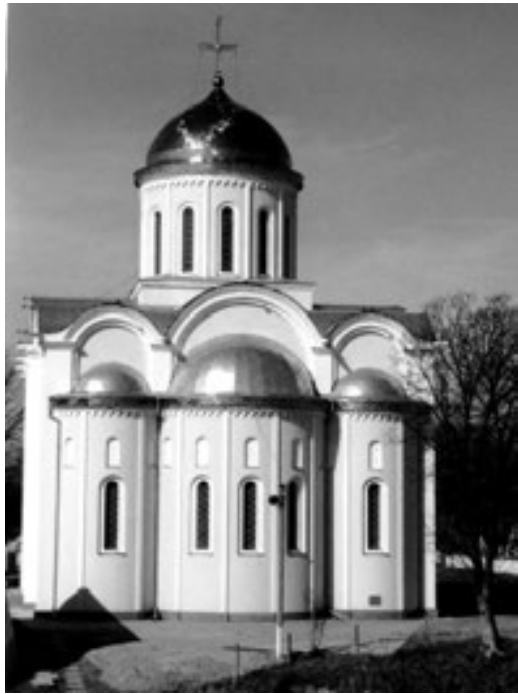

Рис. 22. Успенский собор во ВладимиреВолинськом. Современный вид. Фото автора.

Впрочем, в большинстве случаев редко соблюдалась «чистота» стиля на почве образцов древнерусских, византийских, либо российских допетровской эпохи (XVI XVII вв.). Чаще можно наблюдать творческие эклектичные сочетания различных стилистических признаков. Интересным примером такой комбинации неовизантийских, неороссийских и даже автохтонных стилистических признаков можно считать Воскресенский собор в Ровно (рис. 23), построенный по проекту петербургского архитектора П. Дейнеко в 1890-1895 годы. Вместе с тем, здесь нельзя не заметить отказ от луковичних глав в пользу скорее барочной традиции, хотя в целом соблюдалась верность тогдашней храмостроительной стилистике.

Не уступала ровенскому храму за своими архитектурными особенностями и пространственными параметрами Воскресенская церковь в Остроге (рис. 24), построенная в 1910 году в Остроге на юго-западном предместье, - там, где когда-то находилась старая одноименная деревянная святыня. Однако в отличие от ровенского храма эта церковь получила более выразительную объемно-пространственную композицию, к тому же усиленную в западной части за сет пристройки высокой колокольни с шатровой главой. В то же время в отдельных архитектурных членениях здесь также доминирует тема визайтийской полуциркульной арки в ее конструктивном и декоративно-пластическом выражении. 


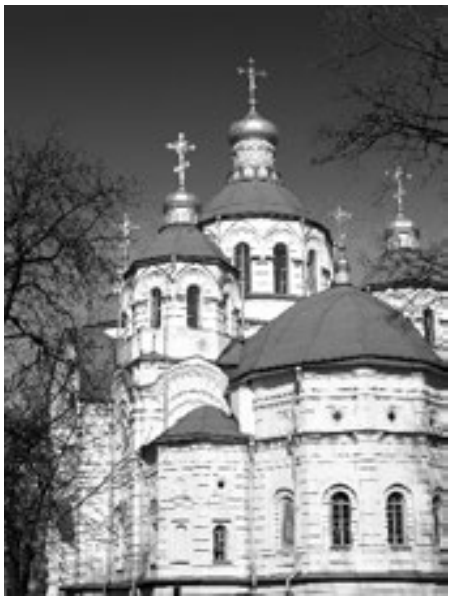

Рис. 23. Воскресенский собор в Ровно. Арх. П. Дейнека. 1895 р. Фото автора.

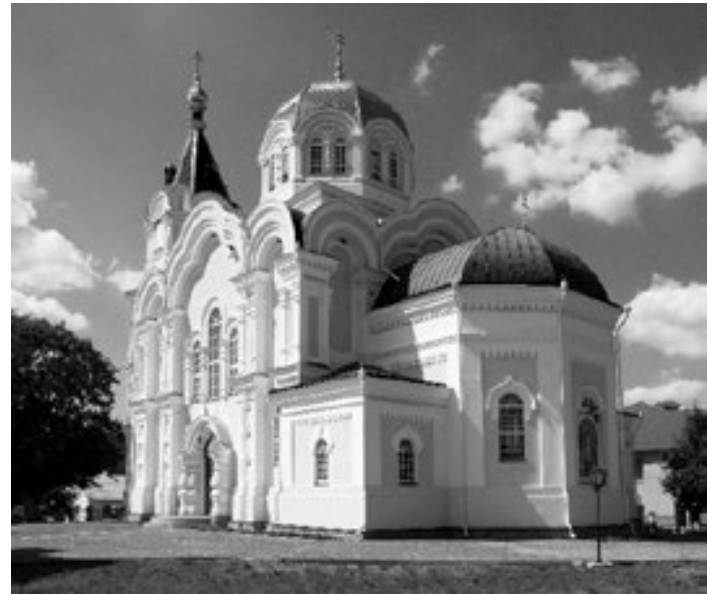

Рис. 24. Воскресенская церковь в Остроге. 1910 р. Фото автора.

Не менее интересный пример использования неовизантийский темы в сумиши с российскими формами можно видеть в с. Быковцы Шумского района Тернопольской обл. Особое отличительная черта здешней каменной церкви Рождества Пресвятой Богородицы (1907 г.) - Тема гигантской арки на северном и южном фасадах главного нефа. Среди других примеров использования неовизантийский стилистики можно выделить каменный храм в юго-волынском селе Гнидава. Здесь на склоне придорожного холма возвышается массивный объем Покровской церкви, построенной в 1914 году. В ее архитектурном облике явно доминирует тема массивных декоративно-структурных арок, образованных нетинькованою кирпичной кладкой. Возможно, именно этот храм является последней реализацией так называемого «кирпичного стиля» в сакральной архитектуре Волыни, в котором причудливым образом переплелись неовизантийская, неорусская и даже неороманская темы.

Вторая половина XIX - начало XX вв. стали также периодом массового строительства нових деревянных церквей. Все они, конечно, уступали каменным по признакам монументальности и представительности, однако бесспорно выигрывали в темпах строительства, его стоимости, а главное - в десятки раз превосходили их количественно. Новое церковное строительство принципиально и вполне осознано пренебрегало местными архитектурными традициями и всячески содействовало распространению неорусских шаблонных примов как по отношению к объемной композиции и относительно стилистических примов.

Вместе с тем, компаративный анализ все же выявляет заметное стремление к формотворческой индивидуализации, прежде всего на уровне архитектурного декора, орнаментики и деталировки. Наиболее распространенными типами деревянных церквей указанного периода стали четырехчастные планированные схемы «колокольня - притвор - неф - алтарь» с нюансными различиями пропорционного строя отдельных частей и общей конфигурации храмового пространства. Наиболее распространенными купольными завершениями были одноглавые (рис. 25) и пятиглавые храмы (рис. 26). В отдельных случаях для обогащения композиции храмы могли дополняться еще и чисто декоративними («слепыми») главками над боковыми ветвями, над алтарем, над притвором, иногда даже над сеньми и внешними пристройками в форме крылец. Достаточно широко варьировались также такие элементы внешней отделки, как дверные порталы, оконные наличники и сандрики, карнизные профили, пилястры и лизены, крыльца, опорные столбы, ограждения и т.п. Собственно именно в этом декоративном 
многообразии прослеживается тяга местных строительных мастеров к индивидуализации декоративных форм и деталей, к приданию ккаждому храму индивидуальних особенностей.

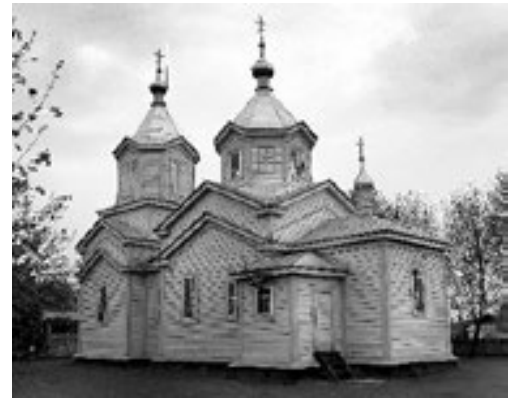

Рис. 25. Деревянная церковь св. Козьмы и Демьяна в с. Буща Дубенского р-на. 1743 г. Пристрока колокольныи 1888г. Фото автора

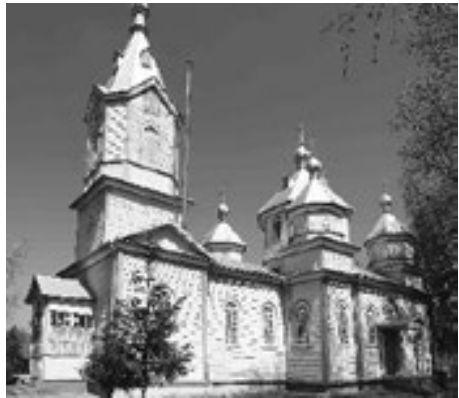

Рис. 26. Деревянная Вознесенская церковь в с. Бугрин Гощанского р-на. 1876 p. Фото автора.

Нельзя обойти вниманием также тот факт, что деревянные церкви, построенные в XVII-XVIII вв. сообразно местным традициям, в имперский период часто подвергались существенным морфологическим трансформациям ${ }^{51}$ с целью придания им «русско-православного» вида ${ }^{52}$. В частности, типичное для Волыни обособленное расположение колоколен заменялось пристройками их при входе, чаще всего с завершениями в виде высоких пирамидальных шатров. По оценкам самих российских авторов, они должны были символизировать «гордость духа ... стремление в высоту ... побег от суеты земной» ${ }^{53}$.

Очевидно, что для таких перестроек были две основные причины. Первой мотивацией было стремление пришлого православного клира к нивелированию местного «малороссийского стиля» (то есть украинского, автохтонного), издавна практиковавшегся на Волыни еще до Брестской унии и представляющего собой уникальное местное наследие. Эти разворачивались в той мере, в какой местный церковный клир пополнялся священнослужителями, делегированными сюда из центральных губерний России. Вторая мотивация при перестройке старих деревянных была связана с недостаточностью государственного финансирования для строительства новых церквей в «синодальном» стиле. Поэтому перестройки старых церквей оказались делом удобным и получили таким образом широкое распространение ${ }^{54}$. Кажется даже, что по масштабам такого трансморфизма Волынь получила первенство в сравнении с другими землями, присоединенными к России после разделов Речи Посполитой. Практика массовых перестроек в направлении «бывший костел - православная церковь», а также «бывшая церковь греко-католическая - церковь православная» получила свое обоснование и в сфере

51 Brykowski R. Drewniana architektura cerkiewna na koronnych ziemiach Rzeczypospolitej. - Warszawa, 1995. - s. 120-122.

52 Годованюк Е. М. К вопросу сохранения архитектурного наследия г. Дубно // Проблемы современной архитектуры и историческое наследие Украины. - К., 1979. - с. 98.

53 Ильин М. А. Русское шатровое зодчество. Памятники середины XVI века. Проблемы и гипотезы, идеи и образы. - М., 1980. - с. 124.

54 Ричков П. Міжконфесійний трансморфізм... - с. 361. 
архитектурной идеологии, варьируясь от пафосного одобрения русской «народной» архитектуры и вплоть до упреков Ф. Достоевского в адрес «ненавистного католицизма» ${ }^{55}$.

Одним из таких типичных примеров архитектурного трансморфизма, имевшего целью стилистическую русификацию, может служить деревянная церковь св. Юрия в селе Сеянцы возле Острога, построенная в 1743 году в традиционной волынской манере, с тремя главами на трех срубах. Однако в 1888 году глава над притвором (бабинцем) была полностью разобрана, а к главному входу достроена колокольня с острым восьмигранным шатром наверху ${ }^{56}$. В таком искаженном виде церковь сохранилась до нашего времени (рис. 27). Подобные пристройки и перестройки исчисляются десятками.

Одним из проявлений усиления роли православной архитектуры на Волыни стали реставрационные акции. Кроме вышеупомянутого Успенского собора во Владимире-Волынском в качестве показательного примера следует вспомнить также восстановление Васильевской церкви в Овруче, осуществленное архитектором А. Щусевым при участии П. Покрышкина, В. Леонтовича, В. Максимова, Л. Веснина (рис. 28). Это хорошо известный пример гипотетической реставрации почти полностью разрушенной архитектурной достопримечательности, который продемонстрировал поиск принципиальных подходов к проведению таких важных восстановительных работ. Однако кроме достижения собственно профессионального, в об щем положительного результата реставрационная акція в Овруче стала еще и символическим вкладом в пафосную идею «возрождения русского духа» на Волыни, широко разрекламированного в российском обществе.

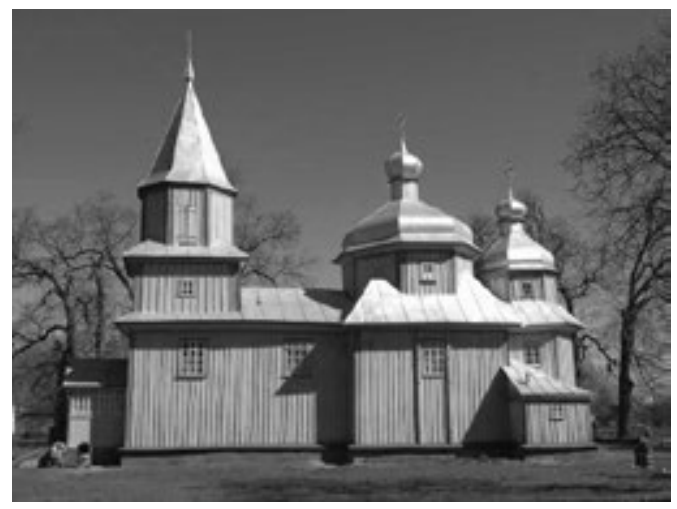

Рис. 27. Церковь св. Юра (Георгиевская) с пристроенной колокольней в с. Сеянцы Острожского р на. Фото автора.

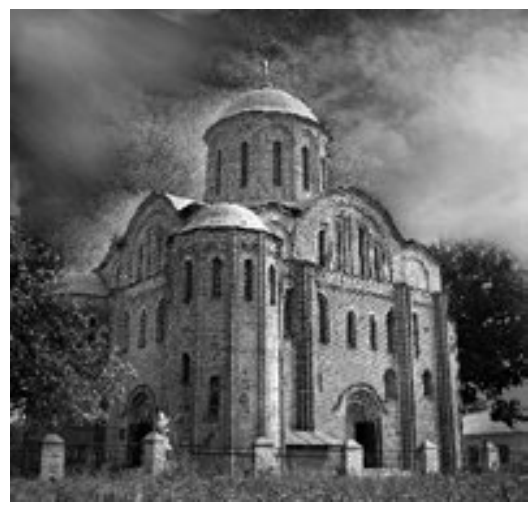

Рис. 28. Реставрация Васильевской церкви в Овруче. Арх. А. Щусєв и др. 1907-1911 гг. Современное фото.

Еще одним символическим шагом в этом направлении стало строительство нового Троицкого собора на территории Почаевской лавры по проекту того же А. Щусева (рис. 29). Здесь молодой архитектор использовал традиционную архитектурную стилистику древнерусского храмового зодчества, соответствовавшую пожеланиям волынского архиепископа Антония (Храповицкого) видеть в Почаеве аналогию древнему Троицкому храму в подмосковной Сергиивской лавре, только в увеличенных размерах. Новый храм, несмотря на высокий профессионализм архитектора, оказался контрастным и даже вызывающим дополнением к уже сложившемуся познебарочному ансамблю. Однако именно такое осознанное противопоставление нового храма греко-католической

55 Кириченко Е. И. Архитектурные теории... - с. 262.

56 Памятники градостроительства... - К., 1985. - Т. 3. - с. 326. 
старине, олицетворенной величественным Успенским собором, очевидно и было главной целью заказчика при выборе архитектурной стилистики ${ }^{57}$.

Характеристика храмостроительного наследия Волыни указаного периода не будет полной без упоминания о своеобразном храме-памятнике на Казацких могилах в с. Пляшева около Берестечко (рис. 30). По устоявшейся атрибуции, храм якобы запроектировал архитектор А. Щусев с участием студента В. Масимова ${ }^{58}$, однако вопрос о мере конкретного творческого вклада каждого из них в конечный результат так и остался до конца не выясненным. Хотя другие, однозначно атрибутированы проектные работы В. Максимова, склоняют нас к мысли, что роль А. Щусева была все же второстепенной. Известно, кстати, что при выборе проектного решения рассматривалась реальная возможность использования здесь русско-византийского стиля как символа борьбы «за единую и неделимую Русь» ${ }^{59}$. Только благодаря инициативе В. Леонтовича и при поддержке самого В. Максимова был принят и реализован вариант, уникальный по своему образно-композиционному решению. Небольшая, однако монументальное по форме здание храма-памятника вместило в себе три престола на трех уровнях, а к тому же получило внешний иконостас в плоскости главной фасадной стены, обрамленной огромной аркой. В стилевом видношенни храм бесспорно имеет семантические параллели с украинским барокко ${ }^{60}$ и одновременно характеризуется как результат определенного воздействия модерна. Благодаря этой постройке в полной мере раскрылся талант молодого архитектора, оставившего на территории Волыни своеобразное произведение сакрального зодчества ${ }^{61}$.

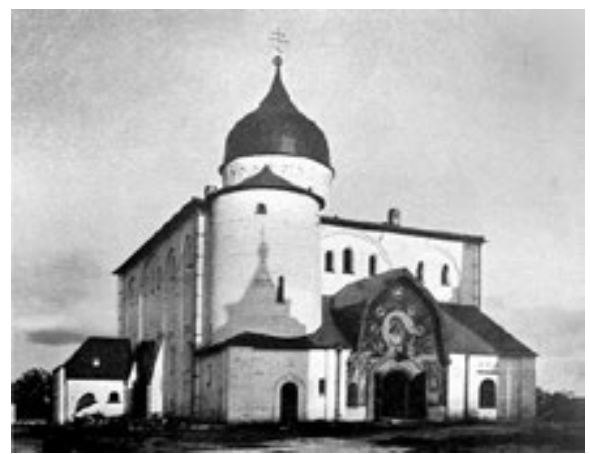

Рис. 29. Троицкий собор Почаевской лавры. Арх. А. Щусєв. 1906-1912 гг. Фото начала ХХ в.

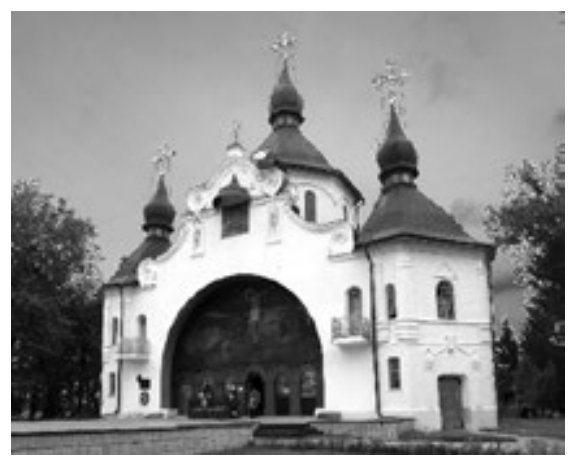

Рис. 28. Храм-памятник на Казацких Могилах возле Берестечка. Арх. В. Максимов. 1909-1914 pp. Фото автора.

57 Див.: Ричков П. А. Луц В. Д. Почаївська Свято-Успенська лавра... - с. 87-94.

58 Крашенинников А. Ф. В. Н. Максимов зодчий русского национального стиля. 1882-1942. - М., 2006. - c. 24-25.

59 Гаврилюк С. Історичне пам'яткознавство Волині, Холмщини та Підляшшя (XIX - початок XX ст.). - Луцьк, 2002. - c. 361.

60 Ясиевич В. Е. Архитектура Украины на рубеже ХІХ-ХХ веков. - К., 1988. - с. 145.

61 Ричков П.А. 1. Володимир Максимов - архітектор Свято-Георгіївської церкви на «Козацьких могилах» // Наукові Записки рівненського обласного краєзнавчого музею. - Вип. ХІІІ. Ч. 1. - Рівне, 2015. - c.215-219. 
Общепризнанным фактом является то, что Брестская церковная уния стала не только толчком для интеграции украинского этноса в европейский культурный контекст, но и весомым мотивом латинизации церковной архитектуры ${ }^{62}$. Последствия этого процесса на Волыни в XVIII в. были довольно показательными, хотя и не такими многочисленными, как это имело место на белорусских землях. Ликвидация польской государственности в конце XVIII в. и вхождение Волыни в состав царской России согласно политической логике обусловили изменение интеграционного вектора этого края. Преференции, предоставленные царской властью для православной церкви, именно на эти изменения и были направлены. В архитектурном смысле это означало переход от проевропейских латинизирующих тенденций в храмостроении XVIII в. к виразительно ориентализации проросийского направления в храмостроении следующего столетия.

Особенно это касалось деревянных храмов ${ }^{63}$. Конечно, можно воспринять традиционный постулат о том, что новые деревянные церкви, построенные на Волыни в российскую эпоху, не были связаны с автохтонными традициями украинского храмостроения. А поэтому они могут характеризоваться как «епархиальна архитектура», привнесенная извне ${ }^{64}$. Впрочем, при более внимательном аналитическом «прочтении» этих многочисленных церквей оказывается, что, переследуя вполне очевидные прозелитические цели и подвергаясь довольно жестким ограничениям в выборе архитектурных решений, эта архитектура тем не менее в своих формообразующих средствах, а особенно в архитектурной деталировке, получала некие индивидуальные черты. Истоки этой индивидуальности следует, очевидно, искать не в каких-либо предписаниях, а в локальном творчестве конкретних архитекторов и в их сотрудничестве с местными мастерами строительного дела.

XIX век принес на Волынь новые семантические образы и храмостроитедльные каноны. В исторических исследованиях почеркивается, что «церкви, построенные в национальном (т.е. неороссийском - П.Р.) стиле символизировали доминирование России в тех регионах, которые сохраняли єлементы религиозной и политической автономии» ${ }^{65}$. Здесь следует отметить, что в административном смысле Волынь не принадлежала к таким регионам и рассматривалась властью как инклюзивная часть единого «русского мира», которая после разделов Польши якобы попросту вернулась в его исконное лоно. Однако в действительности этот регион такой автономией обладал, в том числе и в смысле своего мультикулькурного прошлого, сориентированного в большей степени на Запад, чем на Восток. Тем не менее, в XIX веке имперской властью была предпринята попытка радикально изменить этот вектор, и сакральное зодчество играло в этой стратегии одну из главных ролей.

Впрочем, можно прийти к еще одному важному выводу, что огромное по своим физическим объемам православное храмостроение на Волыни указанного периода, как ни прискорбно признать, в значительной мере «растворило» в себе аутентичные достижения местной архитектурной традиции. Важно также отметить, что этого не случилось на территории соседней Галиции. Это обстоятельство достаточно убедительно изложено в аналитическом изложении патриарха Димитрия ${ }^{66}$. Поэтому в целом был прав Р. Брыковский, характеризуя волынское церковное зодчество второй половины XIX века как

62 Kowalczyk J. Świạtynie późnobarokowe na kresach...

63 Детальніше див.: Ричков П., Смолінська О. Дерев'яні церкви... - с. 363-375.

64 Історія українського мистецтва. - К., 1970. - Т. 4, кн. 2. - с. 48.

65 Wortman R. The "Russian Style" in Church Architecture as Imperial Szmbol after 1881 // Architectures of Russian Identity: 1500 to the Present. - Ithaca and London, 2003. - p. 110.

66 Димитрій, патріарх. Церковне будівництво Західної України. - Львів, 1998. - 68 с. 
явление регрессивное ${ }^{67}$. Показательна также и оценка Ф. Волкова, который отмечал, что синодальная канонизация храмостроительной практики на Волыни в имперский период отличалась бесцветной, неинтересной шаблонностью ${ }^{68}$. Корректно умалчивает об особенностях сакрального зодчества на периферии Российской империи и известный британский исследователь В. К. Брумфилд ${ }^{69}$.

Важным аспектом данной проблемы выглядит также судьба волынской сакральной архитектуры XIX - начала XX в. и в смысле аксиологии, и в оценке ее исторического статуса. В относительно короткий межвоенный период в западной части Волыни, вошедшей в состав второй Речи Посполитой, католическая церковь приложила значительные усилия к восстановлению тех своих святынь, которые были перестроены в православные храмы. Делалось это прежде всего по идеологическим соображениям, и в довольно энергичный способ. Имеющаяся статистика говорит о том, что на Волыни в указанный период царской администрацией были изьяты для приспособления к ортодоксальным канонам или же разрушены 358 католических и униатских храмов ${ }^{70}$. Часть из них во времена второй Речи Посполитой была возвращена прежним конфессиям.

Вместе с тем важно отметить и роль человеческого фактора. Довольно длительный период доминирования на Волыни российского православия, в течение которого сменилось несколько поколений мирян, имел своим следствием постепенное «отмирание» автохтонной храмовой архитектуры и «рождение» новых образно-стилистических канонов. Более того, морфологические стереотипы деревянных церквей, укоренившиеся на Волыни именно в XIX веке, впоследствии даже экспортировались за океан вместе с первой и второй волнами украинской эмиграции - в Канаду, США, страны Латинской Америки ${ }^{71}$.

И когда после обретения независимости украинская церковная архитектура стала снова пополняться многочисленными новостройками, неожиданно оказалось, что занесенные корда-то из чужих краев «неороссийские» («неорусские») прообразы воспринимаются значительной частью местного населения уже как «собственные», адаптированные традиции. Поэтому среди нових реализаций, осуществленных за два последних десятилетия в рамках УПЦ Московского патриархата, неороссийская образно-стилистическая система широко представлена на волынской земле. Чего, опять-таки, практически не наблюдается на соседних территориях, которые в течение почти аналогичного по продолжительности периода времени входили в состав Габсбургской монархии. Напротив, современные храмовые новостройки УПЦ Киевсекого патриархата отчетливо демонстрируют тенденцию к отказу, очевидно вполне сознательному, от подобных церковных архетипов XIX в. и отдают преференции более ранним, автохтонным храмостроительным традициям.

Подытоживая, следует, тем не менее, отметить, что независимо от того, в каких общественно-религиозных и политических условиях развивалось храмостроение на Волыни в указанный период, его разностильное архитектурное наследие остается неотъемлемой, органичной частью историко-культурного ландшафта этого исторического региона. Поэтому это наследие может и должно быть объективно интерпретировано и в полной мере интегровано в новейшую архитектурную историографию. Именно

67 Brykowski R. Drewniana architektura... - s. 113;

68 Волков Ф. К. Старинные деревянные церкви на Волыни // Материалы по этнографии России. - СПб., 1910. - T. $1 .-$ c. 21.

69 Brumfield W.C. Gold in Azure. One Thousand Years of Russian Architecture. - Boston a.o., 1983.

70 Popek L. Świạtynie... - s. 209-217.

71 Галишич Р. Українська церковна архітектура і монументально-декоративне мистецтво зарубіжжя. - Львів, 2002. - c. 9 . 
поэтому оно подлежит профессиональному, подробному и исчерпывающему изучению, а все его характерные образцы должны войти в перечень памятников архитектуры с соответствующими режимами охраны, реставрации и использования для современных нужд различных религиозных общин.

\title{
STYLISTIC EVOLUTION OF VOLHYNIA TEMPLE ARCHITECTURE IN XIX - EARLY XX CENTURIES.
}

\begin{abstract}
An attempt to retrace the main trends in the temple architecture in Volhynia province within the Russian Empire was made in the article. This period was generally characterized by a gradual strengthening of the Russian Orthodox Church and the expulsion of two other Christian denominations: Byzantine-rite Catholic (Uniat) and Roman Catholic. Against this background, in church architecture can be traced the various stylistic currents, based on different artistic paradigms: Classicism (the first third of the 19th century), Romanticism, Gothic, Byzantinism, Neo-Russian Historicism, Art Nouveau, as well as their morphological interferences.
\end{abstract}

Key words: Volhyn Gubernia, temple architecture, Classicism, Romanticism, Gothic, Byzantinism, Neo-Russian Historicism, Art Nouveau. 